\title{
KEY SUCCESS FACTORS IN ENTERPRISES PRACTICING SOCIAL MARKETING
}

\author{
FACTORES CLAVE DEL ÉXITO EN LAS EMPRESAS DE \\ MÁRQUETIN SOCIAL
}

\author{
Mong-Mei Lin mmlin@nutc.edu.tw \\ National Taichung University of Science and Technology. Taichung. Taiwan.
}

\begin{abstract}
Enterprises could create multi-service values of customer satisfaction, enterprise profit, and social benefit through Social Marketing. Constructing a positive Social Service Value Chain to achieve mind management in marketing would reinforce the core competitive advantages of an enterprise, enhance high-quality services, and lead the enterprise to sustainable management. With the Delphi Method, a questionnaire is applied to assess the key success factors in enterprises practicing Social Marketing. The superiors and the employees in Formosa Plastics Group were selected as the research participants for 200 questionnaires. A total of 133 valid copies are retrieved, with a retrieval rate of $67 \%$. According to the overall weights of the key success factors in enterprises practicing Social Marketing, the following summary is concluded. 1. The evaluation criteria in Organizational Characteristics are ordered in the following way: Intrinsic Structure, Internal Environment, Cost Effectiveness, Organizational Advantage, Organizational Weakness, and Inspiration. 2. The evaluation criteria in the External Environment are ordered this way: Information Resources, Environmental Opportunities, and Environmental Threats. 3. The order of the evaluation criteria in Marketing Strategy is Appropriate Media, Targeted Objects, Market Selection, Market Response, and Behavioral Change. 4. The evaluation criteria in Process Orientation are ordered in the following way: Tracking Adjustment, Feedback Systems, Operation Performance, and Operation Processes.
\end{abstract}

\section{KEYWORDS}

Analytic Hierarchy Process (AHP); Environment; Key success factor; Marketing Strategy Social Marketing.

\section{RESUMEN}

A través del márquetin social, las empresas podrían crear valores de multiservicio para la satisfacción del cliente, para incrementar los beneficios de la empresa y para beneficiar a la sociedad. La construcción de una Cadena de Valor de Servicio Social positiva para conseguir una gestión mental en el márquetin reforzaría las principales ventajas competitivas de una empresa, realzaría servicios de alta calidad y llevaría a la empresa a una dirección sostenible. Mediante el Método Delphi, se administra un cuestionario para evaluar los factores clave del éxito en empresas que practican el márquetin social. Se seleccionó a jefes y empleados del Grupo de Plásticos de Formosa para que cumplimentaran 200 cuestionarios. Se consiguió un total de 133 copias válidas, con una tasa de recuperación del $67 \%$. A tenor de la influencia total de cada uno de los factores de éxito clave en empresas que practican el márquetin social, cabe concluir de forma resumida lo siguiente. 1. Los criterios de evaluación de las características organizativas se ordenan de la siguiente manera: Estructura Intrínseca, Entorno Interno, Eficiencia en Costes, Ventaja Organizativa, Debilidad Organizativa e Inspiración. 2. Los criterios de evaluación del contexto externo se ordenan asi: Recursos Informativos, Oportunidades Contextuales y Amenazas Contextuales. 3. El orden de los criterios de evaluación de la estrategia de márquetin es el siguiente: Medios de comunicación Apropiados, Objetivos, Selección de mercados, la Respuesta de mercado y Cambios de Conducta. 4. Los criterios de evaluación de la orientación de procesos son los siguientes: Seguimiento de Ajustes, Sistemas de Feedback, Resultado de la Operación y Procesos de Operación.

\section{Palabras Clave}

Contexto social; Estrategia de Márquetin; Factor clave del éxito; Márquetin social; Proceso Analítico Jerárquico (AHP). 


\section{INTRODUCTION}

Under the evolution of marketing, the integration of satisfying organizational business principles, customer demands, and social benefits has become the mainstream in marketing. The concept of marketing has changed from business competition to customer satisfaction and has focused on the core subjects and social principles concerned by the public. The combination of public relationships and marketing could build up favorable brand images and enhance customer satisfaction. Social Marketing, a series of planning steps of planning, execution, and evaluation, aims to induce purchases and enhance consumer satisfaction as well as deliver information and images conforming to consumers' demands, expectation, concerns, and benefits through the public-trusted media. Based on the overall vision, mission, morality, and responsibilities, an enterprise with culture and mind could apply Social Marketing to successfully play the role of creating social value and social benefits as well as reinforcing the core competition advantages to enhance high-quality services and lead the enterprise to comprehensive success. In other words, enterprises with the vision of mind could create multi-service values of customer satisfaction, enterprise profits, and social benefits through Social Marketing. To effectively integrate and promote social responsibilities, Formosa Plastics Group established a Social Responsibility Promotion Center to promote various social responsibilities within its organization. The Forestation Group and Energy Saving and Carbon Reduction Group were established under the promotion center, and the business units and special departments in the factories were included according to the obligation, expecting to reduce energy consumption and pollution and create harmonious ecological environments. On the other hand, Yung-ching Wang and Yung-tsai Wang sponsored six foundations which played critical roles in promoting social responsibilities of Formosa Plastics Group. Insisting on the principle of "Getting from the society, utilizing for the society", Formosa Plastics Group has actively invested in social benefit programs and has devote devoted itself to promoting social care and reducing social problems. Formosa Plastics Group undertakes the social responsibilities of corporate governance, environmental protection, and social benefits and presents outstanding outcomes to the shareholders, clients, suppliers, employees, nation, environment and resources, and community and society with constant effort in the past half century. Formosa Plastics Group is therefore selected as the research subject.

\section{LITERATURE REVIEW}

\section{Social Marketing}

The American Marketing Association (AMA) defines marketing as an organizational function to create, communicate, and provide value for customers and the process to 
manage customer relationships so that both the organization and the stakeholders are benefited (Huang, 2009).

Kotler et al. (2002) defined Social Marketing as a means to influence the targeted objects to voluntarily accept, refuse, correct, or give up certain behaviors by applying the principles and technology of marketing and to further promote the benefits of individuals, groups, or societies. Such a definition was based on marketing. Su (2011) indicated that the people engaging in Social Marketing initially believed in the ideas to provide the optimal solutions for specific "social problems" that Social Marketing aimed to solve (Wang, 2012). Andreasen (2002) considered Social Marketing as a process to develop social changes, which was constructed according to the marketing model in private sectors. He mentioned that enhancing social concepts was not the entire scope of Social Marketing. Instead, the ultimate objective was to change individual behaviors and Social Marketing could facilitate the changes of education or attitudes. Chang (2010) indicated that Social Marketing did not provide social products based on individual preferences, as general commercial marketing did, but promoted concepts and behaviors which were not actually accepted by the public. In this case, Social Marketing was based on social benefits to point out the problems of groups which regarded themselves as normal, propose solutions, and induce the targeted groups to voluntarily change their current situations (Sargeant, 1999). Scrivens (1991) therefore pointed out behavioral changes as the emphasis of Social Marketing, which tended to have the targeted objects accept a new behavior, refuse a habitual behavior, correct a current behavior, or give up an old behavior through marketing (translated by Yu et al., 2011). Kotler and Lee (2007) further modified the definition of Social Marketing as influencing the targeted objects, with marketing principles and technology, to voluntarily accept, refuse, correct, or give up a behavior for an individual, group, or social benefits in order to improve the quality of life of the public (Bloom et al., 1981).

Kotler (1982) concluded four tasks of Social Marketing, which particularly focused on the attitudes and behavioral changes of the targeted objects (Weng, 2010). (1) Enormous new information needed to be delivered and the public identity had to be acquired for arousing the public to pay attention to marketing issues, such as informing the public about the pollution which results from randomly discarding trash, the nutrition value of various types of food, and the hazard of drugs, so as to enhance Social Marketing with Cognitive Change. (2) Causing temporary action changes, such as encouraging the public to donate blood and females receiving breast cancer screening and attracting parents to attend to the education of secure children drug use, could promote Social Marketing with Actionable Change. (3) It is more difficult to try to change people's permanent behaviors and learn new behaviors than in acquiring identity and short-term actions, such as quitting smoking and alcohol, changing diet habits or routines. This tends to promote Social Marketing with Behavioral Change. (4) The promotion of Social Marketing with Value Changes tends to change people's beliefs and values. Nevertheless, people's values are oftentimes firmly rooted and practicing Social Marketing could be a most difficult task. 


\section{Key success factors in Social Marketing}

Social Marketing broadly covers marketing issues. Kotler, Roberto \& Lee (2002) presented 50 major social issues from the investigation of successful Social Marketing cases in the USA and classified such issues into categories such as health promotion, injury prevention, environmental protection, and community involvement (Table 2-7); where the organizations actually applied Social Marketing containing governmental institutes, non-profit organizations, profit sectors, and professional marketing companies (translated by Yu et al., 2011). It is worth noting that voluntary behavioral changes are the major products sold by Social Marketing workers. In terms of behavioral changes, the targeted objects are expected to complete (1) accepting a new behavior, (2) refusing a habitual behavior, (3) correcting a current behavior, and (4) giving up an old behavior. Moreover, traditional marketing 4Ps, i.e. product, price, place, and promotion, are also emphasized in Social Marketing.

Kotler, Roberto \& Lee (2002) concluded that there are 12 key success factors in Social Marketing, covering (1) acquiring the past successful experiences and knowledge, (2) starting from well-prepared targeted objects, (3) creating a feasible behavior with a simple and definite slogan, (4) enhancing Behavioral Change with the application of Assisted Entity or Services, (5) reinforcing Cost Effectiveness in Behavioral Change, (6) simplifying the process, (7) developing the information to be able to draw attention and inspiring behaviors, (8) using Appropriate Media for increasing the participation of the public, (9) providing a Feedback System for enhancing the public application of simple and convenient strategic change behaviors, (10) distributing appropriate Information Resources to maximize the information, (11) enhancing the success of plans by moderate research, and (12) tracking the results and proceeding with adjustments (translated by Yu et al., 2011). Sun (2009) analyzed Social Marketing with the factors of Organizational Characteristics, External Environment, Marketing Objectives, Strategic Change Objects, and Marketing Strategy. The Organizational Characteristics contained the Internal Environment, Intrinsic Structure, Operation Process, Operation Performance, Organizational Advantages and Organizational Weaknesses. The External Environment included External Environmental Opportunity and External Environmental Threats. Marketing Strategy was analyzed with the traditional 4Ps of marketing (Kotler and Armstrong, 2001).

\section{RESEARCH DESIGN AND METHODOLOGY}

\section{Establishment of Evaluation Criteria}

The Delphi Method was developed and proposed by Olaf Helmer et al. in 1950, aiming to acquire the consistent opinions of experts and specific objects. However, the convergent effect was not significant because of distinct expert opinions that the number of investigation times was increased in the process of Delphi Method. Moreover, the mean 
was used for screening the evaluation criteria and the statistics were likely affected by extreme values. It therefore showed the drawbacks of time-consuming processes, high investment costs, low retrieval rate, and fuzziness and distortion of expert opinions. A Fuzzy Delphi Method was therefore applied to screen the key criteria in this study. Being an expert prediction approach, the Delphi Method was included in the Fuzzy Theory after the proposal of L.A. Zadeh. In the applications, a Fuzzy Delphi Method replaces the mean algorithm with a geometric mean for the decision groups screening the evaluation criteria. In this case, it does not show distortion and avoids the statistical effects of extreme values and the selected criteria appear with optimal effects.

The questionnaires are sent to the experts in different fields through emails. The first feedback is organized and the considerations for enterprises practicing Social Marketing are further classified for seeking and incorporating the experts' opinions. Such requests are run through several times via emails for all experts setting the key success factors in Social Marketing in the expert conference. Such factors are regarded as the dimensions for AHP, and the correspondent criteria are established within the AHP questionnaire. Figure 1 shows the research framework after being modified with the Delphi Method.

\section{Research Participant}

Formosa Plastics Group established in 1954, started from a small-scale PVC powder manufacturer and grew into a multinational corporation in the international petrochemical industry. The businesses cover oil refineries, petrochemicals, plastics, textiles, fiber, electronics, energy, transportation, machinery, and biotechnology. With their efforts in the past 50 years, most of the business scales and performance have achieved an international standard and has even led the world. Based on the philosophy of contributing to the society, it has invested in non-profit medical and educational businesses and has continuously assisted the societies' disadvantaged groups for completing enterprise responsibilities. As a result, Formosa Plastics Group is selected as the research subject, and the management team and employees are considered as the participants. A total of 200 questionnaires were distributed and 133 valid copies were retrieved, with a retrieval rate of $67 \%$.

\section{ANALYSIS OF THE RESULTS}

\section{Evaluation Criteria in Hierarchy li of The Hierarchy Analysis}

After the questionnaire survey, the evaluation standard for the key success factors in enterprises practicing Social Marketing in Hierarchy II of Hierarchy Analysis is acquired. Such data are calculated from the geometric mean of importance between paired criteria to form the Hierarchy Analysis matrix. The consistency ratio C.R. $=0.026<0.1$ reveals the 
Figure 1.

Research framework

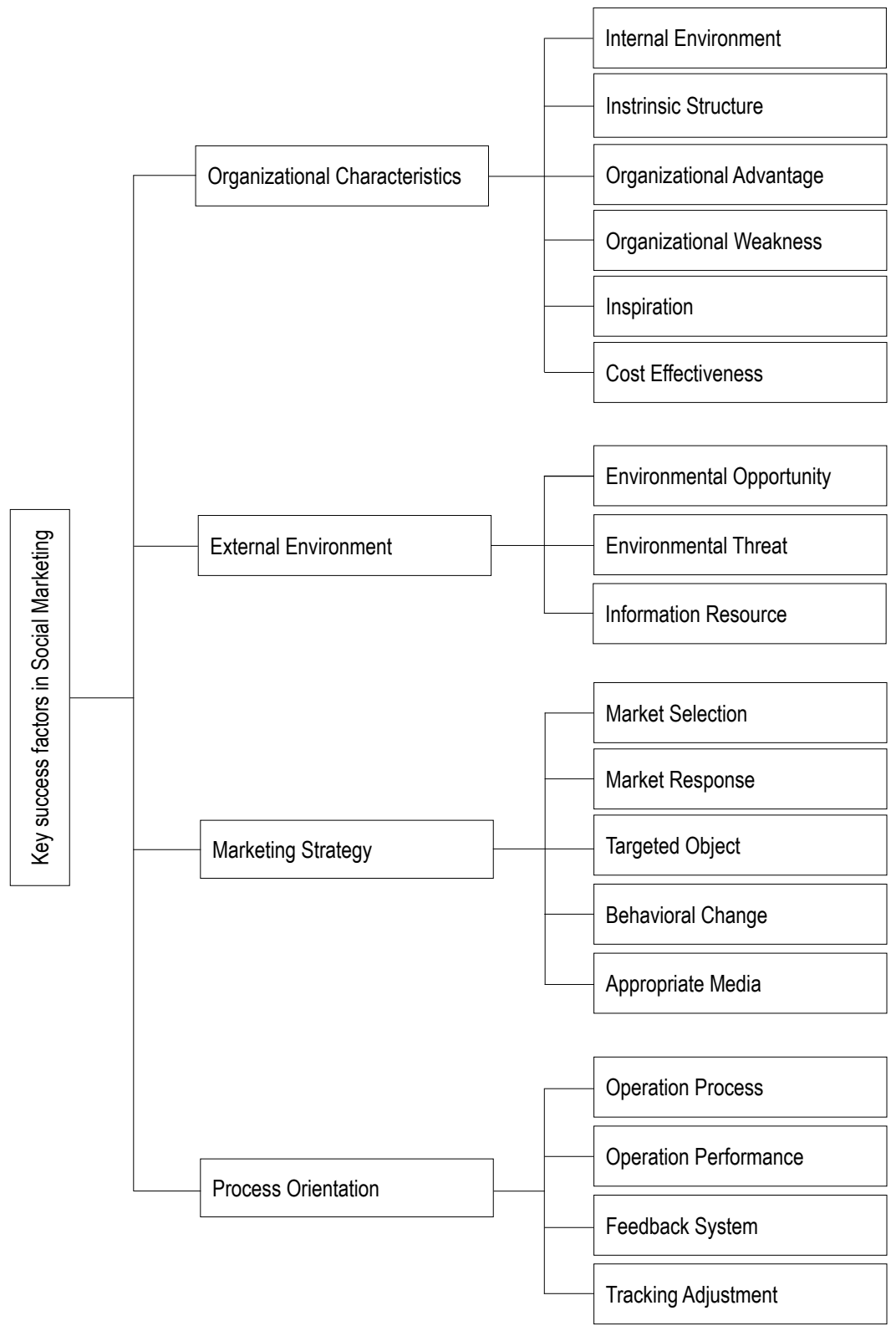


consistent decisions of the experts. The evaluation criteria are ordered by their weights and importance, Table 1, as Organizational Characteristics, Process Orientation, Marketing Strategy, and External Environment.

Table 1.

Weights of key success factors in Social Marketing

\begin{tabular}{c|lc}
\hline Order of weight & \multicolumn{2}{|c}{ Key success factors in Social Marketing } \\
\hline 1 & Organizational Characteristics & 0.376 \\
4 & External Environment & 0.108 \\
3 & Marketing Strategy & 0.235 \\
2 & Process Orientation & 0.281 \\
\hline
\end{tabular}

\section{Overall Consistency Evaluation of Hierarchy Analysis}

Having completed all hierarchical weights, the relative importance of the criteria in the hierarchies is distributed for the overall weight of Social Marketing, Table 2. The results present the top five criteria, within the 18 evaluations, as Intrinsic Structure, Tracking Adjustment, Appropriate Media, Internal Environment, and Information Resources.

Table 2.

Overall weight of Social Marketing

\begin{tabular}{l|l|c|c|c}
\hline \multicolumn{1}{c|}{ Dimension } & \multicolumn{1}{|c|}{ Criteria } & Weight in Hierarchy 3 & Overall weight & Order \\
\hline \multirow{5}{*}{ Organizational } & Internal Environment & 0.201 & 0.081 & 4 \\
Characteristics & Intrinsic Structure & 0.247 & 0.093 & 1 \\
& Organizational Advantage & 0.165 & 0.048 & 12 \\
& Organizational Weakness & 0.153 & 0.033 & 15 \\
& Inspiration & 0.060 & 0.011 & 18 \\
& Cost Effectiveness & 0.174 & 0.062 & 8 \\
\hline \multirow{2}{*}{ External } & Environmental Opportunity & 0.316 & 0.059 & 9 \\
Environment & Environmental Threat & 0.252 & 0.043 & 13 \\
& Information Resource & 0.432 & 0.077 & 5 \\
\hline \multirow{5}{*}{ Marketing } & Market Selection & 0.182 & 0.056 & 10 \\
Strategy & Market Response & 0.148 & 0.051 & 11 \\
& Targeted Object & 0.219 & 0.066 & 7 \\
& Behavioral Change & 0.113 & 0.016 & 17 \\
& Appropriate Media & 0.338 & 0.085 & 3 \\
\hline \multirow{3}{*}{ Process } & Operation Process & 0.154 & 0.021 & 16 \\
Orientation & Operation Performance & 0.216 & 0.038 & 14 \\
& Feedback System & 0.273 & 0.073 & 6 \\
& Tracking Adjustment & 0.357 & 0.087 & 2 \\
\hline
\end{tabular}




\section{CONCLUSIONS AND SUgGeSTIONS}

From empirical analyses, the following conclusions are proposed, expecting to provide definite directions for enterprises practicing Social Marketing.

According to the overall weight of the key success factors in enterprises practicing Social Marketing, the following conclusions are organized.

1. The evaluation criteria in Organizational Characteristics are ordered Intrinsic Structure, Internal Environment, Cost Effectiveness, Organizational Advantage, Organizational Weakness, and Inspiration.

2. The evaluation criteria in the External Environment are ordered Information Resources, Environmental Opportunity, and Environmental Threats.

3. The evaluation criteria in Marketing Strategy are as ordered: Appropriate Media, Targeted Objects, Market Selection, Market Response, and Behavioral Change.

4. The evaluation criteria in Process Orientation are as ordered: Tracking Adjustment, Feedback System, Operation Performance, and Operation Process.

From the above analyses of the key factors in Formosa Plastics Group practicing Social Marketing, the complete functions of the internal organizational structure, the clear purposes, and the definite objectives are considered as the key factors. Furthermore, the available resources in the organization and the organizational capabilities should be thoroughly understood. It is suggested that each marketing plan should be designed with a definite 4P. External assistance and counseling, experience accumulation, and constant review could help enhance the marketing effectiveness. with regard to the Appropriate Media, the public relationship with the media could be reinforced from routine affairs, such as writing press releases with organizational characteristics, planning the media operation process, and holding relative activities to gradually establish connections with journalists. Each marketing plan is preceded with projects matching up the Social Marketing procedure for establishing the cooperative relationship with manufacturers. Moreover, seeking out professional assistance and counseling of public relationship institutes to actively get acquainted with specific journalists could help understand the observation points for the news topics and value during the interactive communication so as to meet the journalist's demands.

\section{REFERENCES}

Andreasen, Alan R. 2002. "Marketing Social Marketing in the Social Change Marketplace." Journal of Public Policy \& Marketing, 21: 3-13.

Bloom, P. N. and Novelli, W. D., 1981, "Problems and Challenges in Social Marketing." Journal of Marketing, 45(2):79-88. 
Chang, Chung-chao 2010. "To explore the meaning, contents, and future development of social marketing." Review of Social Sciences, 33:295-310.

Hsiao, Kun-shan \& Yu, Mei-wen 2011. Social Marketing. Taipei: Wu-nan.

Huang, Chun-ying 2009. The world of marketing. Taipei: Commonwealth Publishing.

Kotler, P., 1982, Marketing for nonprofit organizations, New Jersey: Prentice-Hall.

Kotler, P. and Armstrong, G., 2001, Principles of Marketing, New Jersey: Prentice Hall.

Kotler, P. and Lee, N., 2007, Marketing in the Public Sector. A Roadmap for Improved Performance, New Jersey: Pearson Education.

Kotler, P., Roberto, N. and Lee, N., 2002, Social Marketing: Improving the Quality of Life, California: Sage Inc.

Sargeant, A., 1999, Marketing Management for Nonprofit Organizations, Oxford and New York: Oxford University Press.

Scrivens, E. 1991 "Is There A Role For Marketing In the Public Sector?", Public Money \& Management,11(2):17-23.

Sun, Ben-tsu 2009. A Study on Non-Profit Organizations Promote Diversity Management.The Case of Social Welfare Foundation registered in Taipei City Government, Taiwanese Journal of Political Science, 28:163-202.

Su, Wei-yeh 2011. "Policy Marketing: Theory Rebuilding and Practice." The Chinese Public Administration Review, 1(16):1-34.

Wang, Shun-min 2012, "The Social Marketing of NPOs and the Related-issues Discourse in Taiwan". Community Development Quarterly, 115: 53-64.

Wen, hsing-li 2010. Policy planning and marketing. Taipei: Hua Tai Culture.

Mong-Mei LiN is an instructor at the Department of Business Administration, National Taichung University of Science and Technology, No. 4, Jin-Ping St., Taichung, 404, Taiwan, ROC. Her research interests are marketing management, services marketing and management, and the psychology of consumer behavior.

RECEIVED: 7 August 2013

ACCEPTED: 25 March 2014

PUBLISHED ONLINE: 15 May 2014 